\title{
Explore the Problems of Flipped Classroom of College English in Higher Vocational Colleges
}

\author{
Liu Yafang \\ Xijing University, Xi'an, 710123, China
}

\begin{abstract}
Keywords: flipped classroom, Micro learning resource, Massive Open Online Course (MOOC)
\end{abstract}

\begin{abstract}
: flipped classroom refers to that the teachers create their own teaching video according to the content of the classes in advance. Students watch the video to get the explained knowledge at home or outside the classroom, to learn new knowledge according to the content of the video. While watching the video, the students write down the encountered problems, and then go back to the classroom, communicate with the teacher and discuss the method to solve the problems face to face. The Micro learning resource and the MOOC that are widely used now are also the similar teaching mode. Flipped classroom not only lets the students to watch online videos, they also require to communicate with teachers face to face. It does not means that students watch the video aimlessly in isolation, but to do targeted study according to the key content assigned by teachers before the class and list out their problems at the same time. The flipped classroom is just a method, the final purpose is to let the students to obtain most knowledge in the right time.
\end{abstract}

\section{Introduction}

Flipped classroom teaching method is a new type of teaching mode based on network platform. The "Khan Academy" of Salman Khan made a meaningful exploration on this innovation in the information age. This kind of teaching reform provides a chance for students with learning difficulties to study after class, at the same time, it provides a platform for teachers to challenge the traditional teaching mode, display individual teaching ability. This learning model has the advantage that it can let the students fully to gain the initiative in learning, learn to take responsibility for their own learning. No longer liking the traditional classroom, the teacher is a tool for knowledge, and students listen and study passively.

Flipped classroom can help students to learn autonomously, enhance the classroom interaction, improve the efficiency of students learning. As a new teaching mode, the flipped classroom is effective. It only needs the flowing network, the teachers can teach and manage the class easily; the students can independently control, undertake personalized course learning. The interaction mode online and offline between teachers and students makes the students to maintain effective learning state. The flipped classroom has get the good effect in many schools, so the other schools rushed to follow. However, there are always two sides to everything, the flipped classroom has its advantage and feasibility, but if it is for different objects, the result may be greatly different. Then, according to my own experience in the application of flipped classroom teaching, talk about a series of problems in the higher vocational school English teaching of the flipped classroom in order to help improve the reform of English teaching. 


\section{Students have lack of initiative and consciousness of autonomous learning.}

In higher vocational colleges, most of the students are lack of learning initiative and consciousness. The premise condition of flipped classroom is that the students must have learning desire, they are willing to take the initiative to learn. If students do not want to learn, or they think such a learning mode is a kind of obsessive studying, the results will cause greater resistance of students, the effect will be worse. In the process of implementing teaching reform, we should consider the factors of students, their own exploring space should be how big. There is a big difference between China and the United States education modes. American education pays more attention to cultivate students' ability of thinking, so they are good at to deal with this learning mode. While China's education is another kind of teaching mode, Teachers' teaching occupies a dominant position, the students' autonomous learning is weakened. Students have been accustomed to the mode of teacher teaching and students listening, it is difficult for them to adapt the mode of independent thinking and active learning. Thus, if it is lack of regulation in the students' learning before class, there will be a lot of problems. Such as, whether students seriously learn from the video, whether they did really think of the problems in the video, and whether they solve the problems independently, etc, these are all the teaching aspects should be considered. If students failed to think seriously about the problems or to explore the method to solve the problems, then the study way has lost its meaning.

\section{Learning English is a difficult problem for higher vocational students}

According to the survey, in the higher vocational students' learning subjects, English learning is a big problem. Most of the higher vocational students think that English is difficult to learn, so they are lack of learning motivation, this kind of condition has brought problems to higher vocational college English teaching practice in flipped classroom. According to the survey of higher vocational students, most students are not good at English. They regard English as the most difficult course to learn, and even feel bad when talking about English. With the help of the teacher, the English course is very difficult to learn, not to mention the self-study after class. They think that in the flipped classroom mode, just relying on video learning, will not solve the real problems in English learning. English is a language, a tool, it is mainly used for exchanging and communication. In the process of watching the video, the fear of English makes them learning passively, the learning efficiency is not high. Even if some students are willing to take the initiative to learn, but because of the lack of classroom interaction between teachers and students and the language atmosphere, as time passes, they also lost the motivation to learn. Because the English learning, is not only a simple word and grammar learning, more is the repeated imitation and application of language. It is generally accepted that the interactive teaching in the classroom is more effective than the video learning after class. As some students reflect, the real extracurricular in-depth study is not so simple as we think, don't know how to ask the questions, don't know how to find information. If you have a little inspiration of teacher, some questions could be resolved on the spot, but when they study by themselves they have to think for a long time.

\section{Network environment needs further perfecting}

Network is the media platform for flipped classroom. In the current schools, the network teaching is not popular. If the basic network problems are not solved, the implementing of the flipped classroom will be very difficult. Students generally reflect that there is a lot of inconvenience in the learning online by mobile phone or computer, such as the slow network or the signal problem. It will waste a lot of time, also can let students lose patience in learning. Student 
feedback, if the phone network is not open, learning by mobile phone or uploading teaching tasks assigned by the teacher is not very convenient, time and efficiency became a problem. In addition, many students can't control themselves to see other information on the Internet, can't concentrate on studies. Therefore, if the school can provide network environment with pure environment and rich resources, students will make full use of network platform, flipped classroom can really play its advantage.

\section{Teachers should adapt to the reform of teaching, change traditional teaching methods.}

The flipped classroom teaching is a great challenge to teacher. Most teachers have adapted to the traditional teaching mode, so they will face many problems in the actual operation of the flipped classroom, need to spend a lot of time to prepare for class. Teachers' perception and attitudes, will not change to come over immediately in a certain time, this requires a adapting process gradually. Firstly video data preparation and production is a challenge to teachers' ability. The quality of the teaching video has important effect on the students in after-school learning. The degree of communication between teachers and students is an important factor for success in flipped classroom. In the implementation process of flipped classroom, the quality of teaching video, guidance to communication between students, learning time arrangement, organization of class activities, these all have important influence on teaching effect. Teachers should keep pace with the times in the network teaching platform, guide students to actively communicate.

\section{The teaching material should be practical, providing language show platform for students.}

College English textbooks, should be from the principle of practicability and professional, aim at training professional talents to adapt social development .flipped classroom takes extended teaching based on the excellent teaching material content. At present, some of the obsolete teaching curriculum contents, will only make the students feel dull, without much enthusiasm. The content is out of the students' real life, or is professional to their major. In this case, the effect of flipped actual operation will be discounted. Because the students have no interest in the learning content, they are also not interested in the flipped classroom. And excellent teaching material, can not only give students targeted and professional knowledge, but also can quickly form an English practical environment centering on the teaching material at the same time. In the relatively loose environment, students can communicate with each other, learn from each other, improve the learning interest, make full use of time and resources, efficiently learn English and professional knowledge.

\section{The strategies and methods to solve the problem}

In view of the situation of students' English level is uneven, at the time of implementing flipped teaching method, must help students to change ideas, correct learning attitude. Teachers can choose hierarchical teaching when necessary, in view of the different levels of students to make different learning plans. The teachers should ask the students to have notes about the problems when they watching the video and directly to show their achievements and put forward the encountered problems in the classroom instruction. Teachers review in a timely manner and give positive evaluation according to students' performance, fully mobilize the enthusiasm and initiative of student learning. 


\section{Problems in flipped classroom should be paid attention to}

\subsection{Whether the micro video is must}

Consider a question seriously before making the formal video: whether the video is the suitable teaching tool for teaching effect I expect. If it is yes, then begin to design the video, don't to do video just for a video.

What is a good micro video? Firstly, it can reflect the main thinking clearly, it is short but prominent, students know what they have learned, also know what they want to get in class; Secondly, it is vivid and attractive, make full use of all available modern teaching technology.

Many teachers think what will they speak in the video before ready to record the video, that is the problem "what type of class is the flipped classroom suitable for". In the video, the teacher can tell students the concept of quadratic function, can teach students steps to observe cell, can demonstrate how to solve this problem in the video, and so on, but we through the dictation in the video to train students' practical ability, communication ability and can't to explore the ability of cooperation, so for some high demanding of emotional attitude values class, micro video just guide a bit learning effect.

\subsection{Whether can achieve the three dimensional goal.}

Many teachers found through practice, if we hope our students to preview seriously according to the requirements, they have any certain depth of understanding on the new lesson before the class, then the selected course content must meet two mainly conditions: 1). The knowledge points are fixed and regular 2).It is easy for students to study by themselves. The first one accorded with the front view and often this part of content is more suitable for the video. The second one is contained by the students' ability, but the teacher must control the difficulty of the students' previewing, then it is achievable for students to complete part of the knowledge and skills through previewing. Because every teacher has different understanding and interpretation on the same thing, so the content of emotional things is better to returned to the classroom. In liberal arts, there is more things about emotional attitude values, therefore, for the liberal arts disciplines, want to do a good job in flipped classroom is more difficult than it in science class. The difference between liberal arts and science subject is from the different goals requirement of the three dimensional. We also analyzed the differences and connections between the flipped classroom and the traditional classroom, stick to learning objectives must be effectively, procedural goal must can check measurable, further consider whether flipping is must, before class. flipped classroom can not become a new generalization of the curriculum reform, "great leap forward movement" throwing the teacher's, or become a new type of assistant for exam oriented education .

\subsection{What are we flipping and what should we stick to.}

For many teachers, the process of flipped classroom is : recording video- sending videostudying - to discuss in class - and then discuss to solve the problem - the summary. It is probable that students follow same process of learning in the same class of all disciplines. Certainly, the same learning way is not suitable for the characteristics of each subject, cannot satisfy the needs of each subject. Learning like assembly line, how can students to keep interest and passion? What is the teaching aim of the flipped classroom? What is the purpose of implementing the flipped classroom? By flipping the classroom, what do we want the student to obtain?

Students' self-study is doing see micro class and the guiding case. The students are studying hard, and they are just understand knowledge, applying knowledge and solving the problem, not to discover problems, to find a way, to explore the knowledge, to experience the process of knowledge, to experience a sense of discovering and exploring. It means that we just flip the knowledge, rather 
than learning method. The reformation of the internal learning style should be reflected in the students' learning method and emotional value.

\section{Conclusion}

School must cultivate strong interest in learning, good habits, the scientific method, and a sound personality while teaching students no matter use what means, should be conducive to the cultivation of the student interest, habit and method. That is to say, the implementation of the flipped classroom must be more conducive to complete implementation of the three-dimensional target. The implementing of the goal of knowledge and skill, process and method, emotional attitude and value should not be ignored in order to achieve the goal of knowledge. This is what we should stick to in change.

\section{Acknowledgments}

The author wishes to acknowledge the support of scientific research funds: Research on Flipped Class of College English (15JK2173), Education Department of Shaanxi Province.

The author wishes to acknowledge the support of scientific research funds: Research on Teaching Mode of College English (JGYB1653), Xijing University, Shaanxi .

\section{References}

[1] Li Jia-hou. The management and application digital campus construction and application of new technology training "course" of the development. Shanghai normal university press. 2014.

[2] The application of flipping class in information technology teaching in high school. The information technology education in China. 2013 (12).

[3] Design of flip case classroom teaching based on the interactive whiteboard. 2013.

[4] The application of the "flip" model in the computer foundation teaching. Reading and writing (education teaching research). 2014 (7).

[5] Research on learning support services for flipping class. China distance education (comprehensive). 2014 (5). 